\title{
STUDI KESTABILAN TEKANAN DARAH PADA PENDERITA HIPERTENSI DAN FAKTOR YANG MEMPENGARUHINYA
}

\author{
Suci Khasanah ${ }^{1}$, Maria Paulina Irma Susanti ${ }^{2}$ \\ ${ }^{1}$ Program Studi D3 Keperawatan Univeristas Harapan Bangsa \\ sucikhasanah@shb.ac.id \\ ${ }^{2}$ Program Studi D3 Keperawatan Univeristas Harapan Bangsa \\ mariapaulina@uhb.ac.id
}

\begin{abstract}
ABSTRAK
Ketidakstabilan tekanan darah merupakan keadaan dimana tekanan darah berada dalam rentang perubahan yang cenderung tetap. Tekanan darah penderita hipertensi dapat berubah sewaktuwaktu, dan hal ini sulit diprediksi. Bahkan pada beberapa orang perubahan tekanan darah yang jauh meningkat di atas normal terkadang penderita yang bersangkutan tidak dapat merasakan perubahan tersebut. Hal tersebut dapat membahayakan keselamatan penderita.

Penelitian ini bertujuan untuk mengetahui kestabilan tekanan darah dan faktor yang berkorelasi pada penderita hipertensi di Desa Tambaksogra wilayah kerja Puskesmas 1 Sumbang.

Desain penelitian menggunakan rancangan observasional analisis study cross sectional. Besar sampel pada penelitian ini 42 responden, dengan teknik cluster sampling. Pengamatan tekanan darah dilakukan selama 6 hari, dengan setiap hari dilakukan pengukuran faktor yang mempengaruhinya. Analisis menggunakan lamda dan koefisien kontingensi.

Hasil penelitian menunjukan 90,5\% responden memiliki tekanan darah tidak stabil (90,5\%). Responden dengan kualitas tidur yang buruk paling banyak memiliki tekanan darah yang tidak stabil $(80,9 \%)$, p value 0.032 ; paling dominan yang mengalami ketidakstabilan tekanan darah tingkat stres normal $(40,5 \%)$, p value 0,143 ; responden obesitas maupun tidak obesitas paling panyak tekanan darah tidak stabil dengan p value 0,898 .

Kesimpulan hampir seluruh responden mengalami ketidakstabilan tekanan darah dalam 6 hari pengamatan dan ada hubungan antara kualitas tidur dengan ketidakstabilan tekanan darah.
\end{abstract}

Kata Kunci : Kestabilan tekanan darah, kualitas tidur, stres, obesitas

\section{ABSTRACT}

Instability of blood pressure is a condition in which the blood pressure is within the range of changes that tends to be constant. The blood pressure on the hypertensive people may change anytime, and it is difficult to be predicted. Even in some cases, the change of blood pressure cannot be felt by the sufferers, although it is much higher than the normal range. This may endanger the sufferers' condition.

This research aimed to know the blood pressure stability and the related factors of hypertensive people in Tambaksogra Village, Community Health Center 1 Sumbang.

This research used observational analysis study design with cross sectional approach. The number of samples was 42 respondents; it was taken by using cluster sampling technique. The observation of blood pressure were done in 6 (six) days with daily measurement of the influencing factors. The data was analyzed by using lamda and coefficient of contingency.

The result of the research showed that 90,5\% of the respondents had unstable blood pressure (90,5\%). The respondents with bad sleep quality were the most respondents who had unstable blood pressure (80,9\%), p value 0,032; dominantly the respondents having unstable blood pressure were those who had normal level of stress (40,5\%), p value 0,143; the obese respondents or non-obese respondents were the most respondents who had unstable blood pressure with $p$ value 0,898 .

It can be concluded that almost all respondents have unstable blood pressure in six days observation and there is a correlation between sleep quality and the instability of blood pressure. Keywords: Blood Pressure Stability, Sleep Quality, Stress, and Obesity

Viua Medika | VOLUME 11/NOMOR 02/MARET/2019 
Viva Medika: Jurnal Kesehatan, Kebidanan, dan Keperawatan, 11 (02), Maret 2019

Suci Khasanah, Maria Paulina Irma Susanti (Studi Kestabilan Tekanan Darah Pada Penderita

Hipertensi Dan Faktor Yang Mempengaruhinya)

\section{PENDAHULUAN}

Hipertensi adalah suatu kelainan dimana tekanan darah di atas nilai nomal. Hipertensi masih menduduki peringkat pertama penyebab penyakit kardiovaskuler, yaitu penyakit jantung koroner yang menyebabkan kematian hingga $45 \%$.

Pada tahun 2025, 30\% penduduk dunia diperkirakan menderita hipertensi. Begitu juga di Indonesia, kasus ini masih menjadi masalah besar. Data statistik terbaru menyatakan bahwa terdapat $24,7 \%$ penduduk Asia Tenggara dan 23,3\% penduduk Indonesia berusia 18 tahun ke atas mengalami hipertensi pada tahun 2014 (Wanti, 2015).

Angka kejadian hipertensi di Indonesia berdasarkan hasil Riset Kesehatan Dasar (Riskesdas) Balitbangkes (2013) menunjukkan prevalensi hipertensi mencapai $25,8 \%$. Prevalensi hipertensi di Jawa Tengah didapatkan data sebesar 26,4\% (Departemen Kesehatan, 2013).

Data Dinas Kesehatan Banyumas pada tahun 2016 menunjukkan peningkatan yang signifikan dari tahun 2015 yaitu 5596 kasus menjadi 7223 kasus hipertensi. Puskesmas 1 Sumbang menempati urutan tertinggi kasus hipertensi se Kabupaten Banyumas pada tahun 2016. Pada tahun 2015 terdapat 464 penderita hipertensi, kemudian meningkat menjadi 828 penderita hipertensi pada tahun 2016 (Dinkes Banyumas, 2016). Laporan diagnosis penyakit rawat jalan di Puskesmas 1 Sumbang bulan Desember menunjukkan bahwa hipertensi berada di urutan ke 2 sebanyak 314 orang dengan jumlah terbanyak di Desa Tambaksogra berjumlah 48 orang (Laporan Bulanan Data Puskesmas 1 Sumbang, 2016).

Hipertensi dan komplikasinya dapat dicegah dengan gaya hidup sehat dan mengendalikan faktor risiko. Pencegahan hipertensi dilakukan dengan cara menerapkan pola hidup yang sehat, berhenti merokok, mempertahankan berat badan dalam kondisi normal, mengatasi stres dan emosi, menghindari minuman beralkohol, dan memeriksakan tekanan darah secara berkala (Departemen Kesehatan RI, 2010).

Hipertensi menjadi salah satu penyebab paling umum dari fluktuasi 
Viva Medika: Jurnal Kesehatan, Kebidanan, dan Keperawatan, 11 (02), Maret 2019

Suci Khasanah, Maria Paulina Irma Susanti (Studi Kestabilan Tekanan Darah Pada Penderita

Hipertensi Dan Faktor Yang Mempengaruhinya)

tekanan darah. Tekanan darah dapat berfluktuasi secara signifikan jika seseorang memiliki penyakit hipertensi yang tidak diobati atau tidak dapat dikontrol (Erin, 2014). Tekanan darah penderita hipertensi dapat berubah sewaktu-waktu, bahkan setiap detik tekanan darah penderita hipertensi dapat berubah.

Hasil penelitian sebelumnya menunjukkan bahwa ketidakstabilan tekanan darah pada penderita hipertensi dipercepat oleh beberapa faktor, diantaranya adalah faktor umur, kualitas tidur, stres, obat antihipertensi, konsumsi makanan yang asin atau mengandung banyak garam, obesitas, olahraga dan merokok. Serangkaian penelitian yang dilakukan oleh Gangwisch et al (2006), Bansil et al (2011), Winarsih dkk (2012), Sulastri dkk (2012), Noegroho dkk (2013), Keyzer et al (2014), Setyanda (2015) menyebutkan bahwa usia, stres, olahraga, obesitas, kualitas tidur, kebiasaan merokok dan makanan yang mengandung banyak garam serta makanan yang mengandung pengawet merupakan faktor yang menyebabkan ketidakstabilan tekanan darah pada penderita hipertensi.

Hasil survey yang dilakukan oleh Setiani pada tanggal 17 sampai 19 Januari 2017 terhadap 10 orang penderita hipertensi didapatkan 90\% orang mengalami ketidakstabilan tekanan darah. Dari 90\% orang yang mengalami ketidakstabilan sebagian besar $(66,7 \%)$ merasa tidurnya tidak berkualitas dan merasa hidupnya tidak berkualitas karena sering merasakan tidak nyaman.

Berdasarkan uraian latar belakang di atas maka penulis tertarik untuk melakukan penelitian mengenai faktor-faktor yang mempengaruhi ketidakstabilan tekanan darah khususnya pada penderita hipertensi.

\section{METODE PENELITIAN}

Penelitian dilakukan di Desa Tambak Sogra Kecamatan Kembaran Wilayah Kerja Puskesmas Kembaran 1. Desain penelitian menggunakan rancangan observasional analisis study cross sectional. Besar sampel pada penelitian ini 42 responden. Besar sampel ditentukan dengan rumus solvin, dari besar populasi penderita hipertensi 48 orang, dengan teknik 
Viva Medika: Jurnal Kesehatan, Kebidanan, dan Keperawatan, 11 (02), Maret 2019

Suci Khasanah, Maria Paulina Irma Susanti (Studi Kestabilan Tekanan Darah Pada Penderita

Hipertensi Dan Faktor Yang Mempengaruhinya)

pengambilan sampel cluster sampling.

Cluster yang digunakan adalah 5 wilayah RW yang ada di Desa Tambak Sogra.

Variabel dependent dalam penelitian ini adalah kestabilan tekanan darah. Sedangkan variabel independet yang diteliti meliputi: variabel kualitas tidur, tingkat stres dan obesitas.

Pengamatan tekanan darah dilakukan selama 6 hari berturut turut setiap sore hari dengan setiap hari dilakukan pengukuran faktor yang mempengaruhinya (variabel independet).

Tekanan darah dikatakan stabil bila selama 6 hari tidak mengalami perubahan hasil tekanan darah dan dikatakan tidak stabil bila selama 6 hari mengalami perubahan tekanan darah sebesar $\geq 10 \mathrm{mmHg}$. Kualitas tidur diukur dengan Kuesioner PSQI modifikasi, dengan hasil ukur kualitas tidur buruk dan baik. Sedangkan tingkat stress menggunakan kuisioner DASS, dengan hasil ukur normal, stres ringan, sedang, berat dan sangat berat. penentuan obesitas menggunakan dasar perhitungan IMT, dengan hasil ukur tidak obesitas $\left(\leq 25 \mathrm{~kg} / \mathrm{m}^{2}\right)$ dan Obesitas $\left(>25 \mathrm{~kg} / \mathrm{m}^{2}\right)$
Analisis data menggunakan analisis univariate dan bivariate. Analisis univariate untuk menggambarkan masing-masing variabel. Dan analisis bivariate untuk mengetahui hubungan antara variabel. Untuk mengetahui hubungan variabel yang masing-masing berskala nominal analisis statistik yang digunakan adalah Koefisien Korelasi, dan untuk mengengetahui hubungan antar veriabel yang berskala nominal ordinal menggunakan analisis Lamda

\section{HASIL PENELITIAN DAN PEMBAHASAN}

Gambaran kualitas tidur, tingkat stres, obesitas, kestabilan tekanan darah dan kualitas hidup penderita hipertensi di Desa Tambaksogra setelah dilakukan pengukuran selama 6 hari adalah sebagai berikut:

Tabel 1

Kualitas Tidur, Obesitas, Tingkat

Stres, Kestabilan Tekanan Darah

dan Kualitas hidup Penderita Hipertensi di Desa Tambaksogra

\begin{tabular}{llll} 
Variabel & & F & $\%$ \\
\hline $\begin{array}{l}\text { Kualitas } \\
\text { Tidur }\end{array}$ & baik & 6 & 14,3 \\
& buruk & 36 & 85,7 \\
& Total & 42 & 100,0 \\
\hline Obesitas & obesitas & 12 & 28,6 \\
& $\begin{array}{l}\text { tidak } \\
\text { obesitass }\end{array}$ & 30 & 71,4
\end{tabular}


Viva Medika: Jurnal Kesehatan, Kebidanan, dan Keperawatan, 11 (02), Maret 2019

Suci Khasanah, Maria Paulina Irma Susanti (Studi Kestabilan Tekanan Darah Pada Penderita Hipertensi Dan Faktor Yang Mempengaruhinya)

\begin{tabular}{|c|c|c|c|}
\hline & Total & 42 & 100 \\
\hline \multirow[t]{5}{*}{$\begin{array}{l}\text { Tingkat } \\
\text { Stres }\end{array}$} & Normal & 20 & 47,6 \\
\hline & $\begin{array}{l}\text { Stres } \\
\text { Ringan }\end{array}$ & 4 & 9,5 \\
\hline & $\begin{array}{l}\text { Stres } \\
\text { Sedang }\end{array}$ & 11 & 26,2 \\
\hline & $\begin{array}{l}\text { Stres } \\
\text { Berat }\end{array}$ & 7 & 16,7 \\
\hline & Total & 42 & 100 \\
\hline \multirow[t]{3}{*}{$\begin{array}{l}\text { Kestabilan } \\
\text { Tekanan } \\
\text { Darah }\end{array}$} & TD Stabil & 4 & 9,5 \\
\hline & $\begin{array}{l}\text { TD Tidak } \\
\text { Stabil }\end{array}$ & 38 & 90,5 \\
\hline & Total & 42 & 100 \\
\hline
\end{tabular}

Responden dengan kualitas tidur yang buruk paling banyak memiliki tekanan darah yang tidak stabil $(80,9 \%)$. Hasil uji korelasi menunjukan bahwa ada hubungan antara kualitas tidur dengan kestabilan tekanan darah bermakna secara statistik dengan $\mathrm{p}$ value $0,032<$ $\alpha$.

Tabel 1 memberikan informasi bahwa hampir seluruh responden memiliki kualitas tidur yang buruk $(85,7 \%)$ dan tekanan darah yang tidak stabil (90,5\%), sebagian besar tidak obesitas dan paling banyak tidak mengalami stres (normal) (47,6\%). Hubungan kualitas tidur, obesitas dan tingkat stres dengan kestabilan tekanan darah dapat dilihat pada tabel dibawah ini:

Tabel 3

Hubungan Tingkat Stress dengan Kestabilan Tekanan Darah

\begin{tabular}{|c|c|c|c|c|c|c|}
\hline \multirow{3}{*}{$\begin{array}{l}\text { Var Tk } \\
\text { Stres }\end{array}$} & \multicolumn{4}{|c|}{$\begin{array}{c}\text { Kestabilan Tekanan } \\
\text { Darah }\end{array}$} & \multicolumn{2}{|c|}{ Total } \\
\hline & \multicolumn{2}{|c|}{ Tidak Stabil } & \multicolumn{2}{|c|}{ Stabil } & \multirow[b]{2}{*}{$\mathrm{F}$} & \multirow[b]{2}{*}{$\%$} \\
\hline & $\mathrm{F}$ & $\%$ & $\mathrm{~F}$ & $\%$ & & \\
\hline Normal & 17 & 40,5 & 3 & 7,1 & 20 & 47,6 \\
\hline Ringan & 3 & 7,1 & 1 & 2,4 & 4 & 9,5 \\
\hline Sedang & 11 & 26,2 & 0 & 0,0 & 11 & 26,2 \\
\hline Berat & 7 & 16,7 & 0 & 0,0 & 7 & 16,7 \\
\hline Total & 38 & 90,5 & 4 & 9,5 & 42 & 100,0 \\
\hline $\mathrm{p}-\mathrm{v}$ & 0,03 & & & & & \\
\hline $\mathrm{CC}$ & 0,31 & & & & & \\
\hline
\end{tabular}

Tabel 3 menunjukan bahwa paling Tabel 2

Hubungan Kualitas Tidur dengan dominan responden yang mengalami Kestabilan Tekanan Darah ketidakstabilan tekanan darah tidak

\begin{tabular}{|c|c|c|c|c|c|c|c|}
\hline \multirow{3}{*}{ Var } & \multicolumn{4}{|c|}{ Kestabilan Tekanan Darah } & \multicolumn{2}{|c|}{ Total } & mengalami stres (normal) $(40,5 \%)$. \\
\hline & \multicolumn{2}{|c|}{ Tidak Stabil } & \multicolumn{2}{|c|}{ Stabil } & & & \\
\hline & $\mathrm{F}$ & $\%$ & $\mathrm{~F}$ & $\%$ & $\mathrm{~F}$ & $\%$ & \\
\hline Baik & 4 & 9,5 & 2 & 4,8 & 6 & 14,3 & bahwa tidak ada hubungan antara \\
\hline Buruk & 34 & 80,9 & 2 & 4,8 & 36 & 85,7 & kestabilan \\
\hline Total & 38 & 90,4 & 4 & 9,6 & 42 & 100,0 & value $0.143>\alpha$ ) \\
\hline $\mathrm{p}-\mathrm{v}$ & 0,03 & & & & & & \\
\hline $\mathrm{CC}$ & 0,31 & & & & & & \\
\hline
\end{tabular}


Viva Medika: Jurnal Kesehatan, Kebidanan, dan Keperawatan, 11 (02), Maret 2019

Suci Khasanah, Maria Paulina Irma Susanti (Studi Kestabilan Tekanan Darah Pada Penderita

Hipertensi Dan Faktor Yang Mempengaruhinya)

Tabel 3

Hubungan Obesitas dengan Kestabilan Tekanan Darah

\begin{tabular}{lcccccc}
\hline \multicolumn{4}{c}{ Kestabilan Tekanan } \\
Var & \multicolumn{4}{c}{ Darah } & & \\
Obesitas & \multicolumn{2}{c}{ Tidak Stabil } & \multicolumn{2}{c}{ Stabil } & & \\
& F & $\%$ & F & $\%$ & F & $\%$ \\
\hline Obes & 27 & 64,3 & 3 & 7,1 & 30 & 71,4 \\
Tidak & 11 & 26,2 & 1 & 2,4 & 12 & 28,6 \\
obes & & & & & & \\
Total & 38 & 90,5 & 4 & 9,5 & 42 & 100,0 \\
\hline p-v & 0,03 & & & & & \\
CC & 0,31 & & & & & \\
\hline
\end{tabular}

Sebagian besar responden yang mengalami obesitas memiliki tekanan darah yang tidak stabil $(64,3 \%)$, namun responden yang tidak obesitaspun paling banyak memiliki tekanan darah tidak stabil $(26,2 \%)$. Hasil uji korelasi didapatkkan bahwa tidak ada hubungan antara obesitas dengan kestabilan tekanan darah ( $\mathrm{p}$ value $0,898>\alpha$ )

Hasil penelitian menunjukan bahwa hampir seluruh responden memiliki kualitas tidur yang buruk $(85,7 \%)$. Kualitas tidur buruk yang dialami oleh responden dalam penelitian ini kemungkinan dikaitkan dengan pola tidur rata-rata yang hampir dialami oleh orang lanjut usia yaitu kesulitan untuk memulai tidur dan sering terjaga, bahkan kadang mengeluh insomnia dan kesulitan untuk tidur kembali ketika terjaga. Asumsi ini dikaitkan dengan rerata usia responden pada penelitian ini adalah 61,8 tahun dengan usia terendah adalah 34 tahun dan tertinggi adalah 86 tahun. Usia 61,8 tahun termasuk dalam kelompok usia lansia. Sebagaimana pendapat Mubarok (2008) bahwa pada usia > 60 tahun waktu tidur sekitar sekitar 6 jam/hari, 20-25\% tidur REM dan individu dapat mengalami insomnia dan sering terjaga sewaktu tidur. Pada usia ini, tahap IV NREM akan mengalami penurunan, bahkan kadang tidak ada.

Pada penlitian ini hampir seluruh responden memiliki tekanan darah yang tidak stabil selama 6 hari pengamatan. Yang dimaksud dengan tekanan darah yang tidak stabil adalah selama 6 hari pengamatan dalam setiap harinya terjadi fluktuasi $\geq \leq \leq 10$ mmHg. Perubahan tertinggi tekanan darah sistolik yang dialami responden adalah $40 \quad \mathrm{mmHg}, \quad$ sedangkan perubahan tertinggi pada tekanan darah diastolik juga $40 \mathrm{mmHg}$. Perubahan tekanan darah baik sistolik 
Viva Medika: Jurnal Kesehatan, Kebidanan, dan Keperawatan, 11 (02), Maret 2019

Suci Khasanah, Maria Paulina Irma Susanti (Studi Kestabilan Tekanan Darah Pada Penderita

Hipertensi Dan Faktor Yang Mempengaruhinya)

maunpun diastolik adalah naik turun, namun kecenderungannya adalah naik.

Ketidakstabilan tekanan darah yang dialami oleh hampir seluruh responden penelitian ini kemungkinan terkait karateristik tekanan darah penderita hipertensi, dimana tekanan darah penderita hipertensi dapat dengan mudah berubah-rubah, bahkan perubahan tekanan darah dapat terjadi dalam hitungan menit bahkan detik. Hal tersebut dikarenakan perubahan fungsi pada pengaturan tekanan darah dan perubahan struktur pada tubuh penderita hipertensi. Hal ini sebagimana dikemukakan oleh Smetlzer dan Bare (2014) bahwa sebagian besar hipertensi dikarenakan adanya atheroskelerosis dan perubahan pengaturan tekanan darah.

Seiring dengan bertambahnya usia maka kondisi pembuluh darah besar pun akan menjadi lebih sempit dan dinding pembuluh darah akan semakin kaku, yang mana dapat berdampak kepada peningkatan tekanan darah. Oleh karenanya ketidakstabilan tekanan darah pada penelitian ini mungkin juga karena kontribusi usia responden. Hal ini sebagaimana disampaikan oleh
Rahajeng \& Tuminah (2009, dalam Noviningtyas, 2014).

Hasil penelitian ini menunjukan ada hubungan yang cukup signifikan antara kualitas tidur dengan kestabilan tekanan darah dengan $\mathrm{p}$ value $<\alpha$. Pada saat tertidur tubuh akan beristirahat, termasuk sistem kardiovaskuler. Kerja tubuh akan didominasi oleh kerja saraf parasimpatis. Ketika kerja saraf parasimpatis dominan bekerja maka kerja sistem kardiovaskuler akan cenderung menurun. Ketika seseorang terjaga maka tubuh akan didominasi oleh sistem saraf simpatis. Pengaruh kerja saraf simpatis kepada sistem kardiovaskuler adalah meningkatkan kerjanya. Pendapat ini didasarkan pada teori pengaruh saraf autonom kepada kerja sistem kardiovaskuler sebagaimana disampaikan oleh Gayton dan Hall (2014).

Pendapat ini juga sejalan dengan Fitri (2013) yang menerangkan bahwa gangguan tidur yang terus menerus atau sering dialami akan berdampak kepada perubahan fisiologis tubuh yang menyebabkan sistem keseimbangan pengaturan sistem saraf simpatis dan parasimpatis terganggu. 
Viva Medika: Jurnal Kesehatan, Kebidanan, dan Keperawatan, 11 (02), Maret 2019

Suci Khasanah, Maria Paulina Irma Susanti (Studi Kestabilan Tekanan Darah Pada Penderita

Hipertensi Dan Faktor Yang Mempengaruhinya)

Adanya peningkatan kerja sistem simpatis tersebut berperan dalam peningkatan tekanan darah dan sebaliknya aktifitas parasimpatis akan menurunkan tekanan darah.

Kualitas tidur yang buruk dapat merujuk pada adanya gangguan tidur yang membuat responden mempersepsikan kualitas tidurnya buruk. Kualitas tidur yang buruk mencakup : durasi tidur yang kurang, gelombang tidur yang terganggu, mendengkur, dan hal lain yang mengganggu tidur sehingga mengganggu juga keseimbangan sistem tubuh.

Aktifitas tidur dalam tubuh manusia diatur oleh pusat kesadaran yang terdapat di medulla batang otak dan melibatkan sistem hormonal yang diatur oleh hormon kortisol. Hormon kortisol ini merupakan hormon yang sangat berperan dalam pengaturan irama sirkardia manusia. Ketidakseimbangan hormon kortisol di dalam tubuh akan mengakibatkan ketidakseimbangan hormon yang akan dihasilkan oleh kelenjar adrenal. Kortisol akan berpengaruh terhadap kerja katekolamin yang akan dihasilkan oleh medula adrenal.
Katekolamin terdiri dari epinefrin dan norepinefrin yang bekerja pada sistem saraf (Fitri, 2013).

Kerja sistem saraf akan mempengaruhi kerja pembuluh darah. Kerja saraf simpatis yang bekerja dominan akan menyebabkan vasokontriksi pembulu darah. Vasokontriksi pembuluh darah membuat diameter pembuuh darah semakin mengecil. Mengecilnya diameter pembuluh darah dapat meningkatkan tahanan perifer pada dinding pembuluh darah. Dan tahanan perifer yang meningkat berdampak kepada peningkatan tekanan darah.

Pendapat tersebut juga sejalan dengan yang disampaikan oleh Pallagini et al (2013), bahwa kekurangan tidur dapat menyebabkan peningkatan aktifitas neuroendokrin stress system, peningkatan aktiftas saraf simpatik noctural dan peningkatan citokine pro inflamatory sistem imun. Peningkatan aktifitas neuroendokrin stress system akan meningkatkan rangsang terhadap hipotalamic pituitary adrenal (HPA) dan simpatik adrenal medular (SAM). Peningkatan rangsang terhadap HPA dan SAM akan meningkatkan sekresi 
Viva Medika: Jurnal Kesehatan, Kebidanan, dan Keperawatan, 11 (02), Maret 2019

Suci Khasanah, Maria Paulina Irma Susanti (Studi Kestabilan Tekanan Darah Pada Penderita

Hipertensi Dan Faktor Yang Mempengaruhinya)

noradrenalin, adrenalin dan cortisol. selanjutnya berkontribusi kepada Peningkatan hormon tersebut ketidakstabilan tekanan darah mereka.

sebagaimana telah dibahas Hasil penelitian ini juga sejalan sebelumnya pada akhirnya akan dengan hasil penelitian Palagini et al meningkatkan tekanan darah. (2013) bahwa perubahan tidur, kurang Peningkatan aktifitas saraf simpatik tidur dan insomnia berhubungan noctural sebagaiman telah dijelaskan sebelumnya memicu peningkatan tekanan darah, bahkan disampaikan hal tersebut dapat menyebabkan penyakit pada kardiovaskuler. Sedangkan akibat peningkatan citokinin pro inflamatory pada sistem imum akan menyebabkan terjadinya disfungsi endotelial pada pembuluh darah sehingga menyebabkan terbentuknya plak. Peningkatan plak pada pembuluh darah menyebabkan aliran darah tidak laminar dan diameter pembuluh darah juga semakin menyempit. Hal tersebut dapat menyebabkan tekanan darah meningkat.

Insomnia yang berkempanjangan/kronis dan tidur NREM yang kurang juga akan memicu respon imun inflamatory. Dengan demikian tidak menutup kemungkinan kualitas tidur yang buruk pada responden penelitian ini kurangnya tidur NREM yang dengan peningkatan tekanan darah dan risiko hipertensi. Namun penelitian tidak sejalan dengan penelitian yang dilakukan oleh Noviani dkk (2011), Pitaloka, Utami dan Novayelinda (2015), Tavasoli, Saeidi dan Hooman (2015) yang menunjukan bahwa tidak ada hubungan antara lama tidur dengan perubahan tekanan darah sistolik dan diastolik pada lansia dengan hipertensi. Hasil penelitian yang tidak sejalan kemungkinan dikarenakan perbedaan responden. Pada penelitian yang hasilnya tidak sejalan respondennya adalah remaja dan anak-anak. Sementara pada penelitian ini respondennya adalah usia dewasa dan rata-rata adalah lansia.

Ketidaksabilan tekanan darah penderita hipertensi dapat disebabkan oleh tingkat stres. Kajian tingkat stres pada penelitian ini dilakukan setiap hari selama 6 hari berturut-turut seiring dengan pengamatan tekanan 
Viva Medika: Jurnal Kesehatan, Kebidanan, dan Keperawatan, 11 (02), Maret 2019

Suci Khasanah, Maria Paulina Irma Susanti (Studi Kestabilan Tekanan Darah Pada Penderita Hipertensi Dan Faktor Yang Mempengaruhinya)

darah. Hasil penelitian menunjukan bahwa dari semua responden yang stres berat $(16,7 \%)$ dan sedang $(26,2 \%)$ semuanya memiliki tekanan darah tidak stabil. Namun hampir separoh responden $(47,6 \%)$ berada pada katagori stres normal dan hampir seluruhnya $(40,5 \%)$ memiliki tekanan darah yang tidak stabil. Hasil analisis univariate menunjukan bahwa tidak ada hubungan antara tingkat stress dengan ketidakstabilan tekanan darah.

Hasil penelitian ini tidak sejalan dengan penelitian yang dilakukan oleh Gasperin et al (2009) dan Rahayu (2012) bahwa ada hubungan yang signifikan antara stres dengan kejadian hipertensi. Stres akan memicu mengingkatkan resistensi pembuluh darah perifer dan keluaran jantung. Stres dapat memicu pengeluaran hormon kortisol dan epinefrin yag berhubungan dengan imunosupresi, aritmia dan peningkatan tekanan darah dan denyut jantung.

Ketidakstabilan tekanan darah juga dapat disebabkan oleh obesitas. Kajian obesitas dilakukan berdasarkan indek masa tubuh responden. Pengukuran berat badan dan tinggi badan pada penelitian ini dilakukan secara rutin selam 6 hari berturut-turut seiring dengan pengukuran tekanan darah. Hasil penelitian menunjukan sebagian besar responden $(71,4 \%)$ adalah obes dan hampir seluruh dari yang obes $(64,3 \%)$ memiliki tekanan darah tidak stabil. Begitu juga dengan yang tidak obes $(28,6 \%)$, hampir seluruh dari yang tidak obes $(26,2 \%)$ memiliki tekanan darah yang tidak stabil. Hasil analisis bivariate menunjukan bahwa tidak ada hubungan antara obesitas dengan ketidakstabilan tekanan darah.

Hasil penelitian ini sejalan dengan penelitian yang dilakukan oleh Pramana (2016) dan Rahayu (2012) bahwa tidak ada hubungan yang signifikan antara obesitas dengan tingkat hipertensi. Perbedaan hasil penelitian ini kemungkinan dikarenakan perbedaan variabelnya. Pada penelitian ini variabel yang diteliti adalah kestabilan tekanan darah, sementara pada penelitian sebelumnya variabel yang diteliti adalah hipertensi.

Obesitas merupakan ciri khas dari populasi hipertensi. Daya pompa jantung dan sirkulasi volume darah penderita obesitas dengan hipertensi Viua Medika | VOLUME 11/NOMOR 02/MARET/2019 
Viva Medika: Jurnal Kesehatan, Kebidanan, dan Keperawatan, 11 (02), Maret 2019

Suci Khasanah, Maria Paulina Irma Susanti (Studi Kestabilan Tekanan Darah Pada Penderita

Hipertensi Dan Faktor Yang Mempengaruhinya)

lebih tinggi dibandingkan dengan penderita yang memiliki berat badan normal.

Peningkatan Indeks Masa Tubuh (IMT) berkaitan erat dengan peningkatan tekanan darah baik pada laki-laki maupun perempuan. Individu yang mengalami obesitas lebih berisiko menderita hipertensi dibandingkan dengan individu yang tidak mengalami obesitas (Roslina, 2008). Sebagaimana yang disampaikan Black dan Izzo (1999) dalam Rahayu (2012).

\section{KESIMPULAN DAN SARAN}

\section{Kesimpulan}

Ada hubungan antara kualitas tidur dengan ketidakstabilan tekanan darah pada penderita hipertensi di Desa Tambaksogra Puskesmas Sumbang 1, dengan arah hubungan positif dimana kualitass tidur yang semakin buruk maka tekanan darah semakin tidak stabil. Namun tidak ada hubungan antara tingkat stres dan obesitas dengan ketidakstabilan tekanan darah serta tidak ada hubungan antara ketidakstabilan tekanan darah dengan kualitas hidup pada penderita hipertensi di Desa Tambaksogra Puskesmas Sumbang 1

\section{Saran}

Untuk responden diharapkan responden lebih memperhatikan kualitas tidurnya dan berusaha untuk mencari upaya untuk meningktkan kualitas tidur. Hasil penelitian dapat juga digunakan untuk memberikan saran terkait pentingnya kualitas tidur bagi penderita hipertensi dan sebagai upaya tindakan dalam memberikan asuhan keperawatan pada hipertensi. Selanjutnya dapat dilakukan penelitian terkait yang sama dengan desain yang lebih tinggi dari penelitian ini atau dapat dilakukan penelitian terkait upaya tindakan untuk meningkatkan kualitas tidur dan pengaruhnya terhadap kestabilan tekanan darah.

\section{DAFTAR PUSTAKA}

Bansil, Pooja, et al, 2011, Associations between Sleep Disorders, Sleep Duration, Quality of Sleep, and Hypertension: Results from the National Health and Nutrition.

Brunner \& Suddarth, 2013, Keperawatan Medikal-Bedah Edisi 8 Volume 2, Jakarta : EGC

BPDPK Kementrian Kesehatan RI, 2013, Riset Kesehatan Dasar. 
Fitri, A,A, 2013, Hubungan Kualitas Tidur Terhadap Kejadian Hipertensi, Skripsi, Fakultas Kedokteran dan Ilmu Kesehatan. Gangwisch, James, E, et al, 2006, Short Sleep Duration as a Risk Factor For Hyipertension

Ganong, William F, 2008, Buku Ajar Fisiologi Kedokteran, Jakarta : EGC

Ganong \& McPhee, 2010, Patofisiologi Penyakit : Pengantar Menuju Kedoketeran Klinis, Jakarta : EGC

Green, J, H, 2008, Fisiologi Kedokteran, Jakarta : Bina Aksara Rupa

Guyton, Arthur C, 2014, Fisiologi Manusia dan Mekanisme Penyakit, Alih bahasa: dr. Petrus Andrianto, Jakarta : EGC

Keyzer, Willem De., et al, 2014, Effect of Sodium Restriction on Blood Pressure of Unstable or Uncontroled Hypertensive Patients in Primary Care.

Kowalak., et al, 2012, Buku Ajar Patofisiologi, Jakarta : EGC.

Magfirah, Inun, 2016, Hubungan Kualitas Tidur dengan Tekanan Darah pada Mahasiswi Program Studi S1 Fisioterapi Angkatan 2013 dan 2014 di Universitas Hasanuddin, Skripsi, Program Studi Fisioterapi Fakultas Kedokteran, Universitas Hasanuddin Makasar
Musini, Vijaya M, \& J.M. Wright, 2009. Factors Affecting Blood Pressure Variability : Lessons Learned from Two Systematic Reviews of Randomized Controlled Trials

Noegroho, Raden T,S, dkk, 2013, Hubungan antara Pola Tidur dengan Tekanan Darah pada Pasien Hipertensi di RSUD dr. Soedarso Pontianak.

Noviani, Okti, dkk, 2011, Hubungan Lama Tidur dengan Perubahan Tekanan Darah pada Lansia dengan Hipertensi di Posyandu Lansia Desa Karang Aren.

Rahayu, Hesti, 2012, Faktor Risiko Hipertensi pada Masyarakat RW 01 Srengseng Sawah, Kecamatan Jagakarsa Kota Jakarta Selatan. Skripsi, Fakultas Ilmu Keperawatan Universitas Indonesia.

Sugiharto, A, 2007, Faktor-faktor Resiko Hipertensi Grade II pada Masyarakat, Tesis, Universitas Diponegoro Semarang

Sulastri, Deimi, dkk, 2012, Hubungan Obesitas dengan Kejadian Hipertensi pada Masyarakat Etnik Minangkabau di Kota Padang

Sunkudon, M,C, dkk, 2015, Pengaruh Senam Lansia terhadap Stabilitas Tekanan Darah pada Kelompok Lansia GMIM Anugerah di Desa Tumaratas 2 Kec. Langowan Barat Kab. Minahasa 
Viva Medika: Jurnal Kesehatan, Kebidanan, dan Keperawatan, 11 (02), Maret 2019

Suci Khasanah, Maria Paulina Irma Susanti (Studi Kestabilan Tekanan Darah Pada Penderita

Hipertensi Dan Faktor Yang Mempengaruhinya)

Sumarni, S, Amiruddin, R, \& Leida, I,

M, T, (2015), Faktor yang

berhubungan dengan kualitas hidup penderita hipertensi di

wilayah kerja Puskesmas

Segeri, Jurnal Unhas, Bagian

Epidemiologi Fakultas

Kesehatan Masyarakat

Universitas Hasanuddin,

Sulawesi 